\title{
Tanggapan Kangkung Darat (Ipomoea reptans Poir.) Terhadap Monosodium Glutamat (MSG) Berbagai Konsentrasi
}

\author{
Response Of Kangkong (Ipomoea reptans Poir.) To Monosodium Glutamate \\ (MSG) Of Various Concentrations
}

\author{
Syam Widi Nugroho, Dody Kastono*)
}

\author{
Departemen Budidaya Pertanian, Fakultas Pertanian, Universitas Gadjah Mada \\ Jalan Flora No. 1, Bulaksumur, Sleman, Yogyakarta 55281, Indonesia. \\ *) Penulis untuk korespodensi E-mail: dody.kastono@ugm.ac.id \\ Diajukan: 18 Juli 2019 /Diterima: 11 Februari 2022 /Dipublikasi: 28 Februari 2022
}

\begin{abstract}
Population growth encourages an increase in the need for food and also nutrition, one of which is through vegetable crops. Kangkong is a plant that is popular and has a short life and high nutrient content. The research was conducted to determine the growth response and yield of Kangkong (Ipomoea reptans Poir.) By giving several monosodium glutamate concentrations. The research was conducted at Rumah Kawat, Faculty of Agriculture, Gadjah Mada University, Yogyakarta in April-May 2019. The research was arranged in a complete random design and the treatment in the form of several monosodium glutamate concentrations consisted of 0,5 g/l, $1 \mathrm{~g} / \mathrm{l}$, and 1,5 $\mathrm{g} / \mathrm{l}$. As a control, the concentration of $0 \mathrm{~g} / \mathrm{l}$ is used. The method used in the research is the quantitative measurement of several parameters, then inputed in the calculation analysis of variance (ANOVA) and further tests using Duncan's multiple range test (DMRT) formula. The results showed that given monosodium glutamate from $1 \mathrm{~g} / \mathrm{l}$ significantly increased the plant height (14,13\%), number of leaves $(28,85 \%)$, total fresh weight (84,21\%), fresh shoot weight (109,25\%), total dry weight $(50,61 \%)$, dry shoot weight (94.84\%), and leaf area (114,011\%) compared to control at 35 days after planting.
\end{abstract}

Keyword: growth; kangkong; monosodium glutamate

\section{INTISARI}

Pertambahan penduduk mendorong peningkatan kebutuhan pangan dan huga gizi salah satunya melalui tanaman sayuran. Kangkung merupakan salah satu tanaman yang digemari masyarakat dan memiliki umur pendek dan kandungan gizi yang cukup tinggi. Penelitian dilaksanakan untuk mengetahui tanggapan pertumbuhan dan hasil tanaman kangkung darat (Ipomoea reptans Poir.) dengan pemberian beberapa konsentrasi monosodium glutamat. Penelitian dilakukan di Rumah Kawat, Fakultas Pertanian, Universitas Gadjah Mada, Yogyakarta pada bulan April-Mei 2019. Penelitian disusun dengan rancangan acak lengkap dan perlakuan berupa konsentrasi monosodium glutamat yang terdiri dari 0,5 g/l, $1 \mathrm{~g} / \mathrm{l}$, dan 1,5 g/l. Sebagai kontrol digunakan konsentasi $0 \mathrm{~g} / \mathrm{l}$. Metode yang digunakan adalah pengukuran kuantitatif beberapa parameter, kemudian dimasukkan dalam rumus perhitungan analysis of variance (ANOVA) dan uji lanjut menggunakan duncan's multiple range test (DMRT). 
Hasil penelitian menunjukkan mulai pemberian monosodium glutamat $1 \mathrm{~g} / \mathrm{l}$ mampu meningkatkan tinggi tanaman $(14,13 \%)$, jumlah daun $(28,85 \%)$, bobot segar total $(84,21 \%)$, bobot segar tajuk $(109,25 \%)$, bobot kering total $(50,61 \%)$, bobot kering tajuk $(94,84 \%)$, dan luas daun $(114,011 \%)$ dibanding kontrol pada 35 hari setelah tanam.

\section{Kata kunci: kangkung darat; monosodium glutamat; pertumbuhan}

\section{PENDAHULUAN}

Tanaman hijau dimanfaatkan sebagai suplemen makanan dan dikonsumsi sebagai kebutuhan sehari-hari. Kandungan vitamin, karbohidrat, dan mineral pada sayuran tidak dapat disubstitusi makanan pokok (Nazaruddin, 1995). Kangkung merupakan sayuran favorit masyarakat Indonesia karena mengandung gizi yang cukup tinggi yaitu berupa vitamin A, B, C, protein, kalsium, fosfor, zat besi, natrium, kalium, lemak, karbohidrat, dan karoten (Pracaya, 2009). Menurut Badan Pusat Statistik 2019 produksi tanaman kangkung mengalami penurunan produksi dari tahun ke tahun. Menurut Wigena dkk. (2006) penurunan produktivitas akibat penggunaan pupuk anorganik diduga erat dengan ketidakseimbangan unsur hara dalam tanah. Penggunaan urea berlebih mengakibatkan pengurasan hara mikro ditanah dan akhirnya mempengaruhi pertumbuhan dan hasil tanaman.

Salah satu upaya mengatasi ketersediaan hara untuk produksi kangkung darat dengan pupuk alternatif. Pupuk alternatif yang bisa digunakan salah satunya dengan menggunakan monosodium glutamat (MSG). Menurut Soelaeman dkk. (2003) penggunakan monosodium glutamat sebagai pupuk alternatif mampu meningkatkan produksi ubi, padi, dan kedelai di Provinsi Lampung. Monosodium glutamat memiliki kandungan unsur $\mathrm{C}, \mathrm{H}, \mathrm{O}, \mathrm{N}$, dan $\mathrm{Na}$ yang bisa digunakan tanaman untuk pertumbuhannya. Berdasarkan pemaparan di atas maka perlu dilakukan penelitian mengenai respon dan hasil tanaman kangkung darat terhadap pemberian monosodium glutamate sebagai pupuk alternatif.

Batang kangkung bulat dan berlubang, berbuku-buku, dan banyak air (herbacious). Memiliki percabangan banyak dan setelah tumbuh lama batangnya akan menjalar (Djuariah, 2007). Kangkung memiliki tangkai daun pada buku-buku batang dan di ketiak daunnya terdapat mata tunas yang dapat tumbuh menjadi percabangan baru. Bentuk daun umumnya runcing ataupun tumpul, permukaan daun sebelah atas berwarna hijau tua, dan permukaan bawah berwarna hijau muda. Bentuk bunga kangkung umumnya berbentuk seperti terompet dan daun mahkota bunga berwarna putih atau merah lembayung (Maria, 2009).

Buah kangkung berbentuk bulat telur didalamnya berisi tiga butir biji. Bentuk buah kangkung seperti melekat dengan bijinya. Warna buah hitam jika tua dan hijau ketika muda. Buah kangkung darat 
berukuran kecil sekitar $10 \mathrm{~mm}$, dan umur buah kangkung tidak lama. Bentuk biji kangkung bersegi-segi atau tegak bulat. Berwarna cokelat atau kehitam-hitaman, dan termasuk biji berkeping dua. Pada jenis kangkung darat biji kangkung berfungsi sebagai alat perbanyakan tanaman secara generatif (Maria, 2009).

Kangkung darat dapat tumbuh pada daerah beriklim panas, dan dingin. Jumlah curah hujan untuk pertumbuhan tanaman ini berkisar 500-5000 mm/tahun. Pada musim hujan tanaman kangkung pertumbuhannya sangat cepat dan subur, asalkan di sekelilingnya tidak tumbuh rumput liar (Fikri dkk., 2015). Kangkung darat juga dapat tumbuh pada suhu kisaran $25-30^{\circ} \mathrm{C}$ (Palada and Chang, 2003). Kangkung darat menghendaki tanah subur, gembur banyak mengandung bahan organik dan tidak dipengaruhi keasaman tanah. Tanaman kangkung darat tidak menghendaki tanah yang tergenang karena akar mudah busuk. Tanaman kangkung membutuhkan tanah datar bagi pertumbuhannya, sebab tanah yang memiliki kelerengan tinggi tidak dapat mempertahankan kandungan air secara baik (Haryoto, 2009).

Monosodium glutamat (MSG) dikenal tahun 1960-an, tetapi memiliki sejarah panjang. Pada tahun 1908, Kikunae Ikeda, menemukan asam glutamat sebagai kunci suatu kelezatan makanan. Sementara sebelumnya di Jerman tahun 1866, Ritthausen berhasil mengisolasi asam glutamat dan mengubahnya dalam bentuk monosodium glutamat. Pada tahun 1956 mulai ditemukan cara produksi L-glutamic acid melalui fermentasi. L-glutamic acid inilah inti dari MSG, yang berbentuk butiran putih mirip garam (Halpern, 2002). Monosodium glutamat adalah garam natrium yang berikatan dengan asam amino berupa asam glutamat (Nuryani dan Jinap. 2010). Monosodium glutamat memiliki ruang bangun $\mathrm{C}_{5} \mathrm{H}_{6} \mathrm{NO}_{4} \mathrm{NaH}_{2} \mathrm{O}$ (Ault, 2004).

Dewantri dkk. (2017) menjelaskan unsur natrium pada MSG menunjang pertumbuhan vegetatif dan generatif tanaman, dan memperbaiki pertumbuhan tanaman kekurangan kalium. Unsur nitrogen penting dalam pertumbuhan vegetatif, unsur fosfor untuk pertumbuhan dan perkembangan akar tanaman muda serta menghindari kerdil tanaman akibat kekurangan fosfor. Pemberian monosodium glutamat meningkatkan tinggi tanaman, mempercepat usia tanaman mulai berbunga, menurunkan bobot kering polong, menaikkan jumlah polong bernas, mengurangi jumlah polong hampa dan menaikkan berat 100 biji kacang tanah ( $A$. hypogeae L.) pada pemberian 3, dan $6 \mathrm{~g}$ (Gresinta, 2015). Monosodium glutamat berinteraksi dengan pupuk NPK terhadap tinggi tanaman dan kuncup bunga tanaman rombusa mini di mana $6 \mathrm{~g} / \mathrm{l}$ mampu meningkatkan 54\% dibanding tanpa pupuk (Dewantri dkk., 2017). Pemberian MSG memberikan pengaruh terhadap pertumbuhan vegetatif tanaman pakcoy di mana pemberian $15 \mathrm{~g}$ memberikan hasil 
terbaik dan bila diberikan lebih dari $15 \mathrm{~g}$ akan mengalami kekerdilan tanaman (Novi, 2016). Dengan pemberian MSG pada kangkung diharapkan dapat mempengaruhi hasil tanaman dan menjadikan salah satu alternatif pupuk yang terjangkau masyarakat nantinya.

\section{BAHAN DAN METODE}

Penelitian dilaksanakan di Rumah Kawat, Fakultas Pertanian, Universitas Gadjah Mada pada bulan April-Mei 2019. Penelitian dilaksanakan menggunakan rancangan acak lengkap dengan ulangan sebanyak 3 kali. Perlakuan yang diberikan berupa pemberian MSG konsentrasi $0,5 \mathrm{~g} / \mathrm{l}$ (P1), $1 \mathrm{~g} / \mathrm{l}$ (P2), dan 1,5 g/l (P3). Sebagai kontrol digunakan MSG konsentrasi $0 \mathrm{~g} / \mathrm{l}$ (P0). Pemberian perlakuan dilaksanakan seminggu sekali.

Pengamatan pertumbuhan dimulai pada tanaman berumur 7 hari setelah tanam (hst) dengan interval 4 hari sekali sampai umur 35 hst. Parameter pertumbuhan yang diamati meliputi tinggi tanaman, jumlah daun, bobot segar total, bobot segar tajuk, bobot kering total, bobot kering tajuk dan luas daun. Data pengamatan akan dianalisis dengan analisis varian (ANOVA) pada taraf signifikansi 5\%. Apabila terdapat pengaruh maka dilanjutkan uji duncan's multiple range test (DMRT) pada taraf kepercayaan 95\%.

\section{HASIL DAN PEMBAHASAN}

Hasil penelitian menunjukkan pemberian monosodium glutamat tinggi tanaman, jumlah daun, bobot segar tajuk, bobot kering tajuk, dan luas daun. Uji ragam sidik bobot segar total (Tabel 1) tanaman kangkung darat menunjukkan bahwa pemberian konsentrasi monosodium glutamat memberikan hasil yang berbeda saat 14, 21, dan 35 hst dibanding kontrol. Saat 14 hst pemberian konsentrasi monosodium glutamat $1 \mathrm{~g} / \mathrm{l}$ berbeda nyata dibanding kontrol. Pada 21 hst pemberian konsentrasi $0,5 \mathrm{~g} / \mathrm{l}$ tidak berbeda nyata dibanding kontrol sedangkan pemberian konsentrasi 1 , dan $1,5 \mathrm{~g} / \mathrm{l}$ beda nyata dibanding kontrol. Pada 35 hst pemberian konsetrasi 1 , dan $1,5 \mathrm{~g} / \mathrm{l}$ berbeda nyata dibanding kontrol dan pemberian konsentrasi 0,5 g/l. Pada 14, 21, dan 35 hst pemberian konsentrasi 1 , dan 1,5 g/l memberikan hasil lebih tinggi dibanding kontrol.

Uji ragam sidik bobot segar tajuk (Tabel 2) tanaman kangkung darat menunjukkan bahwa pemberian konsentrasi monosodium glutamat memberikan hasil yang berbeda saat 14,21 , dan 35 hst dibanding dengan kontrol. Saat 14 hst pemberian konsentrasi $0,5,1$, dan $1,5 \mathrm{~g} / \mathrm{l}$ memberikan hasil beda nyata dibandingkan dengan kontrol, sementara pemberian konsentrasi 0,5 , dan $1,5 \mathrm{~g} / \mathrm{l}$ tidak memberikan beda nyata satu sama lain dibandingkan pemberian konsentrasi $1 \mathrm{~g} / \mathrm{l}$. Pada 21 hst pemberian konsentrasi monosodium glutamat berbeda nyata dengan kontrol, sementara pemberian konsentrasi 1 , dan $1,5 \mathrm{~g} / \mathrm{l}$ tidak saling beda nyata satu sama lain dibandingkan pemberian konsentrasi $0,5 \mathrm{~g} / \mathrm{l}$. 


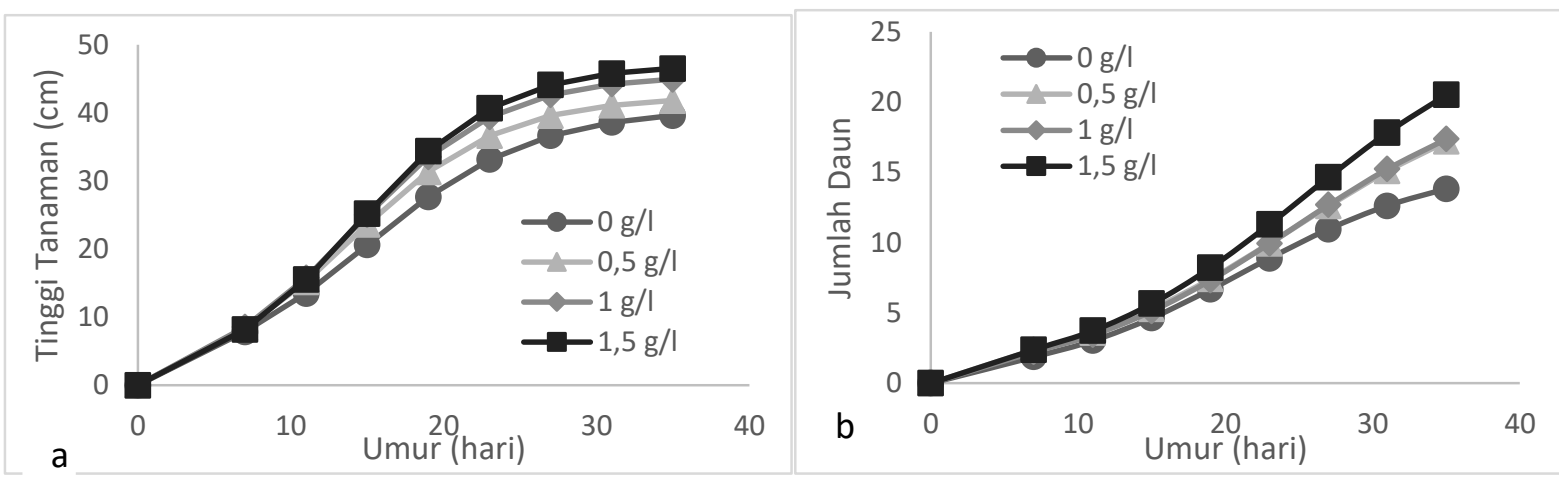

Gambar 1. Dinamika tinggi tanaman (a) dan jumlah daun (b)

Tabel 1. Bobot segar total pada 14, 21, dan 35 hst

\begin{tabular}{ccccccc}
\hline Konsentrasi (g/l) & \multicolumn{5}{c}{ Bobot Segar Total $(\mathrm{g})$} \\
\cline { 2 - 6 } & $14 \mathrm{hst}$ & $21 \mathrm{hst}$ & $35 \mathrm{hst}$ \\
\hline 0 & 0,958 & $\mathrm{~b}$ & 8,758 & $\mathrm{~b}$ & 24,194 & $\mathrm{~b}$ \\
1 & 1,119 & ab & 11,847 & ab & 32,186 & $\mathrm{~b}$ \\
1,5 & 1,574 & $\mathrm{a}$ & 14,414 & $\mathrm{a}$ & 44,567 & $\mathrm{a}$ \\
Koefisien Keragaman (\%) & 1,207 & ab & 14,592 & $\mathrm{a}$ & 43,910 & $\mathrm{a}$ \\
\hline
\end{tabular}

Keterangan: Angka diikuti huruf sama tidak berbeda nyata pada kolom yang sama berdasarkan DMRT tingkat kepercayaan $95 \%$.

Tabel 2. Bobot segar tajuk pada 14, 21, dan 35 hst

\begin{tabular}{|c|c|c|c|c|c|c|}
\hline \multirow{3}{*}{$\begin{array}{c}\text { Konsentrasi }(\mathrm{g} / \mathrm{l}) \\
0\end{array}$} & \multicolumn{6}{|c|}{ Bobot Segar Tajuk (g) } \\
\hline & \multicolumn{2}{|l|}{$14 \mathrm{hst}$} & \multicolumn{2}{|c|}{21 hst } & \multicolumn{2}{|l|}{35 hst } \\
\hline & 0,548 & c & 5,388 & c & 15,029 & $b$ \\
\hline 0,5 & 0,950 & $b$ & 7,400 & $b$ & 20,111 & $b$ \\
\hline 1 & 1,178 & a & 9,506 & a & 31,448 & a \\
\hline 1,5 & 0,906 & $b$ & 9,553 & $\mathrm{a}$ & 31,092 & $\mathrm{a}$ \\
\hline efisien Keragaman (\%) & 11,967 & & 12,4 & & 16,307 & \\
\hline
\end{tabular}

Keterangan: Angka diikuti huruf sama tidak berbeda nyata pada kolom yang sama berdasarkan DMRT tingkat kepercayaan 95\%.

Tabel 3. Bobot kering total pada 14, 21, dan 35 hst

\begin{tabular}{ccccccc}
\hline \multirow{2}{*}{ Konsentrasi $(\mathrm{g} / \mathrm{l})$} & \multicolumn{5}{c}{ Bobot Kering Total $(\mathrm{g})$} \\
\cline { 2 - 6 } & $14 \mathrm{hst}$ & $21 \mathrm{hst}$ & $35 \mathrm{hst}$ \\
\hline 0 & 0,487 & $\mathrm{a}$ & 3,956 & $\mathrm{a}$ & 10,717 & $\mathrm{~b}$ \\
0,5 & 0,478 & $\mathrm{a}$ & 5,183 & $\mathrm{a}$ & 14,197 & $\mathrm{a}$ \\
1 & 0,543 & $\mathrm{a}$ & 5,827 & $\mathrm{a}$ & 16,141 & $\mathrm{a}$ \\
1,5 & 0,434 & $\mathrm{a}$ & 5,968 & $\mathrm{a}$ & 15,869 & $\mathrm{a}$ \\
\hline Koefisien Keragaman (\%) & 24,596 & 19,996 & 9,479 \\
\hline
\end{tabular}

Keterangan: Angka diikuti huruf sama tidak berbeda nyata pada kolom yang sama berdasarkan DMRT tingkat kepercayaan 95\%. 
Pada 35 hst pemberian konsentrasi 1, dan $1,5 \mathrm{~g} / \mathrm{l}$ berbeda nyata dibanding kontrol, dan pemberian konsentrasi $0,5 \mathrm{~g} / \mathrm{l}$. Pada 14 hst pemberian $1 \mathrm{~g} / \mathrm{l}$ memberikan hasil tertinggi, sementara pada 21, dan 35 hst pemberian konsentrasi 1 dan $1,5 \mathrm{~g} / \mathrm{l}$ memberikan hasil tertinggi.

Hasil uji ragam pada bobot kering total (Tabel 3) 14, dan 21 hst tidak ada beda nyata dibanding kontrol. Pada 35 hst pemberian konsentrasi monosodium glutamat ada beda nyata dibanding kontrol. Uji ragam sidik bobot segar tajuk (Tabel 4) tanaman kangkung darat menunjukkan bahwa pemberian konsentrasi monosodium glutamat memberikan hasil yang berbeda saat 14,21 , dan 35 hst dibanding dengan kontrol. Saat 14 hst pemberian konsentrasi $0,5,1$, dan $1,5 \mathrm{~g} / \mathrm{l}$ memberikan hasil beda nyata dibandingkan dengan kontrol, sementara pemberian konsentrasi 0,5 , dan 1,5 $\mathrm{g} / \mathrm{l}$ tidak memberikan beda nyata satu sama lain dibandingkan pemberian konsentrasi $1 \mathrm{~g} / \mathrm{l}$. Pada 21 hst pemberian konsentrasi monosodium glutamat berbeda nyata dengan kontrol, sementara pemberian konsentrasi 1 , dan 1,5 g/l tidak saling beda nyata satu sama lain dibandingkan pemberian konsentrasi 0,5 g/l. Pada 35 hst pemberian konsentrasi 1 , dan $1,5 \mathrm{~g} / \mathrm{l}$ berbeda nyata dibanding kontrol, dan pemberian konsentrasi $0,5 \mathrm{~g} / \mathrm{l}$. Pada 14 hst pemberian $1 \mathrm{~g} / \mathrm{l}$ memberikan hasil tertinggi, sementara pada 21 , dan 35 hst pemberian konsentrasi 1 dan 1,5 g/l memberikan hasil tertinggi.

Hasil uji ragam pada bobot kering tajuk (Tabel 4) pada 14 hst pemberian konsentrasi monosodium glutamat beda nyata dibanding kontrol, untuk pemberian konsentrasi $1 \mathrm{~g} / \mathrm{l}$ beda nyata dengan konsentrasi 0,5 $\mathrm{g} / \mathrm{l}$ dibanding dengan pemberian konsentrasi 1,5 g/l. Pada 35 hst pemberian konsentrasi 1 , dan 1,5 g/l beda nyata dibanding kontrol, dan pemberian konsentrasi $0,5 \mathrm{~g} / \mathrm{l}$.

Hasil uji sidik ragam luas daun (Tabel 5) menunjukkan bahwa pemberian konsentrasi monosodium glutamat beda nyata dibanding kontrol pada 14, 21, dan 35 hst. Pada 14 hst pemberian konsentrasi beda nyata dibanding kontrol, namun pemberian konsentrasi 0,5 , dan $1,5 \mathrm{~g} / \mathrm{l}$ tidak beda nyata satu sama lain dibanding pemberian konsentrasi $1 \mathrm{~g} / \mathrm{l}$. Pada 21 hst pemberian konsentrasi beda nyata dibanding kontrol, sementara pemberian konsentrasi 1 , dan $1,5 \mathrm{~g} / \mathrm{l}$ tidak beda nyata satu sama lain dibanding pemberian konsentrasi $0,5 \mathrm{~g} / \mathrm{l}$. Pada $35 \mathrm{hst}$ pemberian konsentrasi 1 , dan $1,5 \mathrm{~g} / \mathrm{l}$ beda nyata dibanding kontrol, sementara pemberian konsentrasi $0,5 \mathrm{~g} / \mathrm{l}$ beda nyata dengan konsentrasi $1 \mathrm{~g} / \mathrm{l}$, dan tidak beda nyata dengan konsentrasi $1,5 \mathrm{~g} / \mathrm{l}$. 
Tabel 4. Bobot kering tajuk pada 14, 21, dan 35 hst

\begin{tabular}{ccccccc}
\hline \multirow{2}{*}{ Konsentrasi (g/l) } & \multicolumn{5}{c}{ Bobot Kering Tajuk (g) } \\
\cline { 2 - 6 } & 14 hst & 21 hst & 35 hst \\
\hline 0 & 0,077 & $\mathrm{c}$ & 0,586 & $\mathrm{~b}$ & 1,551 & $\mathrm{~b}$ \\
0,5 & 0,119 & $\mathrm{~b}$ & 0,737 & ab & 2,122 & $\mathrm{~b}$ \\
1 & 0,147 & $\mathrm{a}$ & 0,918 & $\mathrm{a}$ & 3,022 & $\mathrm{a}$ \\
1,5 & 0,133 & $\mathrm{ab}$ & 0,929 & $\mathrm{a}$ & 3,051 & $\mathrm{a}$ \\
\hline Koefisien Keragaman (\%) & 10,044 & 14,504 & 13,644
\end{tabular}

Keterangan: Angka diikuti huruf sama tidak berbeda nyata pada kolom yang sama berdasarkan DMRT tingkat kepercayaan 95\%.

Tabel 5. Luas daun $\left(\mathrm{cm}^{2}\right)$ tanaman kangkung darat pada 14, 21, dan $35 \mathrm{hst}$

\begin{tabular}{crrrrrl}
\hline \multirow{2}{*}{ Konsentrasi (g/l) } & \multicolumn{7}{c}{ Luas Daun $\left(\mathrm{cm}^{2}\right)$} \\
\cline { 2 - 7 } & $14 \mathrm{hst}$ & $21 \mathrm{hst}$ & $35 \mathrm{hst}$ & \\
\hline 0 & 10,374 & $\mathrm{c}$ & 85,020 & $\mathrm{c}$ & 297,190 & $\mathrm{c}$ \\
0,5 & 18,358 & $\mathrm{~b}$ & 119,110 & $\mathrm{~b}$ & 380,000 & $\mathrm{bc}$ \\
1 & 23,669 & $\mathrm{a}$ & 153,280 & $\mathrm{a}$ & 636,020 & $\mathrm{a}$ \\
1,5 & 16,909 & $\mathrm{~b}$ & 157,410 & $\mathrm{a}$ & 577,360 & $\mathrm{ab}$ \\
\hline Koefisien Keragaman (\%) & 13,300 & 11,074 & 24,835 & \\
\hline
\end{tabular}

Keterangan: Angka diikuti huruf sama tidak berbeda nyata pada kolom yang sama berdasarkan DMRT tingkat kepercayaan 95\%.

Hasil penelitian menunjukkan meningkatkan tinggi tanaman (14,13\%), pemberian konsentrasi MSG mampu jumlah daun $(28,85 \%)$, bobot segar total memberikan pengaruh terhadap (84,21\%), bobot segar tajuk (109,25\%), pertumbuhan tanaman kangkung darat. Hal bobot kering total $(50,61 \%)$, bobot kering ini menunjukkan pemberian konsentrasi tajuk $(94,84 \%)$, dan luas daun $(114,01 \%)$ MSG mampu diserap tanaman dengan baik karena MSG terlarut diduga memberikan asam amino tersedia yang bisa diserap langsung oleh tanaman. Asam amino tersebut digunakan sebagai pembentukan jaringan pada tanaman.

\section{KESIMPULAN}

Pemberian monosodium glutamat meningkatkan pertumbuhan dan hasil tanaman kangkung meliputi tinggi tanaman, jumlah daun, bobot segar total, bobot segar tajuk, bobot kering total, bobot kering tajuk, dan luas daun dibanding kontrol. Pemberian monosodium glutamat mulai $1 \mathrm{~g} / \mathrm{l}$ mampu

\section{DAFTAR PUSTAKA}

Ault, A. 2004. The monosodium glutamate story: the commercial production of MSG and other amino acids. Chem. Edu., 81(3): 347-355.

Dewantri, M.S., K.P. Wicaksono, dan Sitawati. 2017. Respon pemberian pupuk NPK dan monosodium glutamat (MSG) terhadap pembungaan tanaman rombusa mini (Tabernaemontana corymbosa). Jurnal Produksi Tanaman 5(8): 1301-1307.

Fikri, M. S., D. Indradewa, dan E.T.S. Putra. 2015. Pengaruh pemberian kompos limbah media tanam jamur pada 
pertumbuhan kangkung darat. Novi. 2016. Pemanfaatan monosodium Vegetalika 4(2): 79-89.

Gresinta, E. 2015. Pengaruh pemberian monosodium glutamat (MSG) terhadap pertumbuhan dan produksi kacang tanah (Arachis hypogea L.). Faktor Exacta 8(3): 208-219.

Halpern, B.P. 2002. What's in a name? are MSG and umami the same?. Chem. Sense 27: 845-846.

Haryoto. 2009. Bertanam Kangkung Raksasa di Pekarangan. Kanisius. Yogyakarta.

Maria, G.M. 2009. Respon produksi tanaman kangkung darat (Ipomea reptans

Poir.) terhadap variasi waktu pemberian pupuk kotoran ayam. Jurnal

IImu Tanah 7(1): 18-22.

Nazaruddin. 1998. Budidaya Dan Pengaturan Panen Sayuran Dataran Rendah. Penebar Swadaya. Jakarta.

Sukabumi dengan pemanfaatan pupuk organic dan hayati. Prosiding inovasi teknologi padi menuju swasembada beras berkelanjutan. glutamat dalam meningkatkan pertumbuhan vegetatif tanaman pakcoy (Brassica chinensis L.). Bioconcetta 2(1): 63-74.

Nuryani, H. and S. Jinap. 2010. Soy sauce and it's umami taste: a link from the past to current situation. Journal of Food Science 5(3): 71-76.

Palada, M.C., and L.C. Chang. 2003. Suggested Cultural Practices for Vegetable Amaranth. Vegetable Reseach and Development Center.

Pracaya. 2009. Bertanam Sayur Organik. Penebar Swadaya. Jakarta.

Soelaeman, Y., Wahyunto, dan Sunaryo. 2003. Jurnal Penggunaan Pupuk Cair Limbah Monosodium Glutamat (MSG) pada Tanaman Pangan di Propinsi Lampung.

Balai Penelitian Tanah. Bogor

Wigena, I.G.P., E. Tuherkih, T. Suhartini. 2006. Peningkatan produktivitas lahan sawah dengan intensifikasi di

Pusat Penelitian dan Pengembangan Tanaman Pangan. Badan Penelitian dan Pembangunan Pertanian. 